\title{
Mechanical Properties of Service-Exposed Pendent Superheater Tubes of a Thermal Power Plant
}

\author{
Ashok K. Ray, Yogendranath Tiwari and Satyabrata Chaudhuri \\ Materials Evaluation Division, National Metallurgical Laboratory (CSIR), \\ Jamshedpur-831007, Bihar, India.
}

\begin{abstract}
This paper highlights the high-temperature tensile and the creep rupture properties of pendent superheater tubes, after five years of service exposure, made of $1 \mathrm{Cr}-0.5$ Mo steels in $500 \mathrm{MW}$ boilers of a thermal power plant. Experimentally determined yield strength and ultimate tensile strength as well as estimated 3,000 hours $-100,000$ hours rupture strength, as obtained from experimental data in the temperature range of $500{ }^{\circ} \mathrm{C}$ to $600{ }^{\circ} \mathrm{C}$, exhibit a decreasing trend with increasing temperature. Microstructural study did not reveal any significant degradation in terms of creep cavities, cracks, graphitisation, etc. A general analysis of tensile and creep rupture reveals that the pendent superheater tubes can remain in service for more than five years, provided the temperature of the tube does not exceed $500{ }^{\circ} \mathrm{C}$. It is, however, recommended that a similar health check may be carried out after five years.
\end{abstract}

Key Words: Service-exposed, creep rupture, yield strength, ultimate tensile strength, remaining life.

\section{INTRODUCTION}

Cr-Mo steels are extensively used as boiler tubes in thermal power plants /1-14/. Even though most of these components have a specific design life of about 10 years, many of them operate for even longer.

Pendent superheater tubes, made of $1 \mathrm{Cr}-0.5 \mathrm{Mo}$ steel, in $500 \mathrm{MW}$ boilers of a thermal power plant, have been in continued service for about five years since 1991. The plant people had experienced prevalence of higher steam temperature in the pendent superheater tubes. Hence, during shut-down of the plant in 1996, this study was undertaken to determine mechanical properties of the steel to assess the condition of pendent superheater tubes for their continued service /14/.

The present work thus comprised determination of tensile properties in the temperature range of $25^{\circ} \mathrm{C}$ to $600^{\circ} \mathrm{C}$, creep rupture properties in the temperature range of $500^{\circ} \mathrm{C}$ to $600{ }^{\circ} \mathrm{C}$ and a microstructural study to assess the condition of the service-exposed pendent superheater tubes for their continued service.

The material specifications and the operating parameters of the service-exposed pendent superheater tubes were as follows: 


\subsection{Material specifications}

The material specification for pendent superheater tubes was Grade 620 (1 Cr-0.5 Mo steel) BS3059, Part 1I,1978. The specified outer diameter and thickness of the tubes were $51 \mathrm{~mm}$ and $7.1 \mathrm{~mm}$ respectively. The chemical analysis of this steel is given in Table 1 .

Table 1

Chemical composition of pendent superheater tubes

\begin{tabular}{|l|c|c|c|c|c|c|c|}
\hline \multirow{2}{*}{ Material } & \multicolumn{7}{|c|}{ Elements, Wt\% } \\
\cline { 2 - 8 } & $\mathrm{C}$ & $\mathrm{Mn}$ & $\mathrm{Si}$ & $\mathrm{S}$ & $\mathrm{P}$ & $\mathrm{Cr}$ & Mo \\
\hline $\begin{array}{l}\text { Pendent superheater tube } \\
\text { of Unit -1 }\end{array}$ & 0.14 & 0.42 & 0.32 & 0.02 & 0.032 & 1.08 & 0.48 \\
\hline $\begin{array}{l}\text { Pendent superheater tube } \\
\text { of Unit -2 }\end{array}$ & 0.12 & 0.4 & 0.35 & 0.04 & 0.04 & 1.10 & 0.45 \\
\hline
\end{tabular}

\subsection{Operating parameters}

Steam flow at superheater outlet

Steam pressure at superheater outlet

Steam temperature at superheater outlet

Drum pressure

Steam inlet at first stage

Steam temperature at $4^{\text {th }}$ stage outlet

Metal wall temperature of pendent superheater

near the outlet
: 1600 tons per hour

: $178 \mathrm{~kg} / \mathrm{cm}^{2}$

: $540{ }^{\circ} \mathrm{C}$

: $207.7 \mathrm{~kg} / \mathrm{cm}^{2}$

: $350^{\circ} \mathrm{C}$ (approximately)

: $445^{\circ} \mathrm{C}$ (approximately)

: $480^{\circ} \mathrm{C}$ (approximately)

\subsection{Temperature history}

The plant people provided the actual temperature history from their log books for a period of about three months prior to shut down. The actual temperature on some days shot up as high as $590^{\circ} \mathrm{C}$. The temperatures experienced by the tubes as a function of time are shown in Fig.1. Due to the excessive rise in temperature at stage 4 , the quantity of attemperator water was reported to be as high as 170 tons per hour, which is very close to the maximum capacity of the attemperator, 200 tons per hour. 


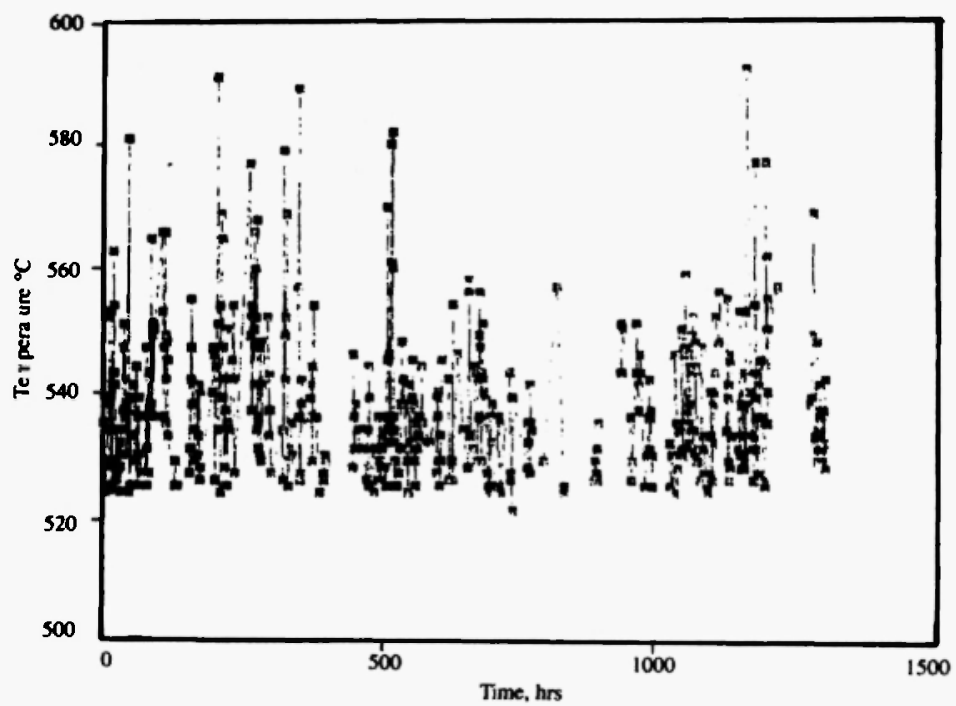

Fig. 1: Trend of tube wall temperature in $4^{\text {th }}$ stage pendent superheater tube over a period of 1500 hours.

\subsection{METHODOLOGY AND INTERPRETATION OF RESULTS}

\subsection{Visual examination}

Pendent superheater tubes selected for this investigation from unit No. 1 are given in Fig.2(a). The dimensional measurement carried out on these tubes did not show any appreciable damage in the O.D.(outer diameter) or the wall thickness, and the cross section of the tube $6 / 6$ was found to be of uniform thickness, as shown in Fig. 2(b). The outer surface of the tube was brownish in color and the thickness of the external oxide scale was normal. There was no evidence of any localised attack on the outer and inner surfaces of the tube. There are $59 \times 2$ elements in the pendent tubes and in each element there are $6 \times 2$ tubes The layout of the tubes is shown schematically in Fig. 3.

\subsection{Mechanical properties:}

\subsubsection{Hardness}

Hardness measurements were carried out on all tubes received for investigation and the results are reported in Table 2. 


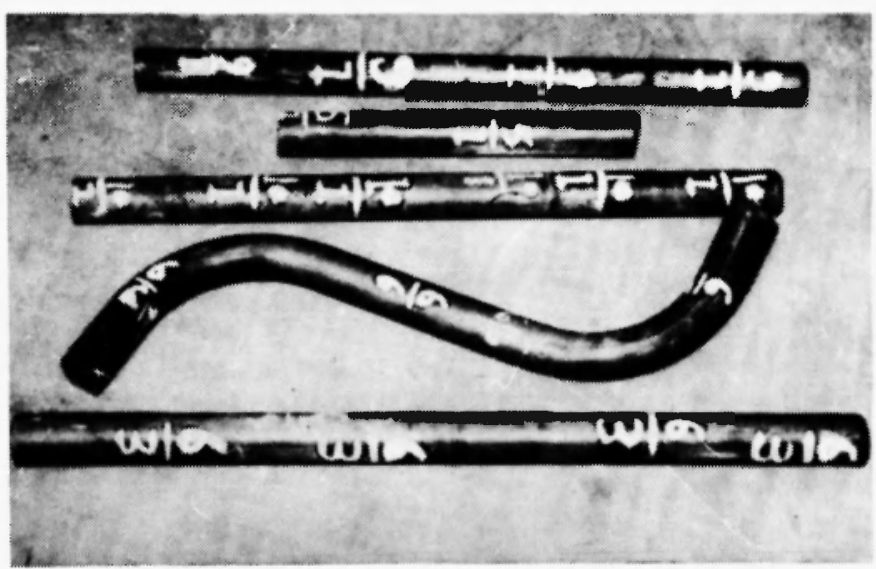

Fig. 2: (a) As received pendent superheater tubes for Unit No. 1, in the present investigation.

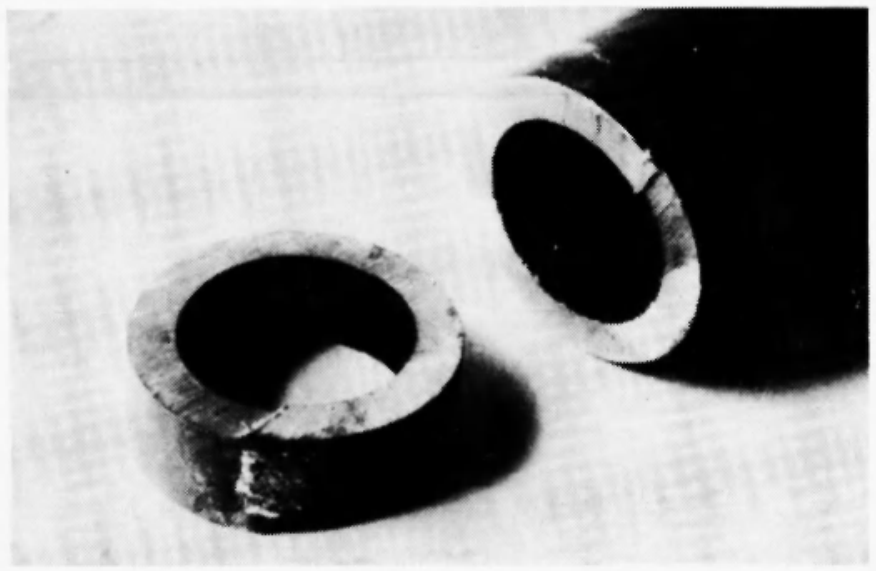

Fig. 2: (b)Transverse section of tube $6 / 6$ for Unit No. 1, revealing uniform thickness.

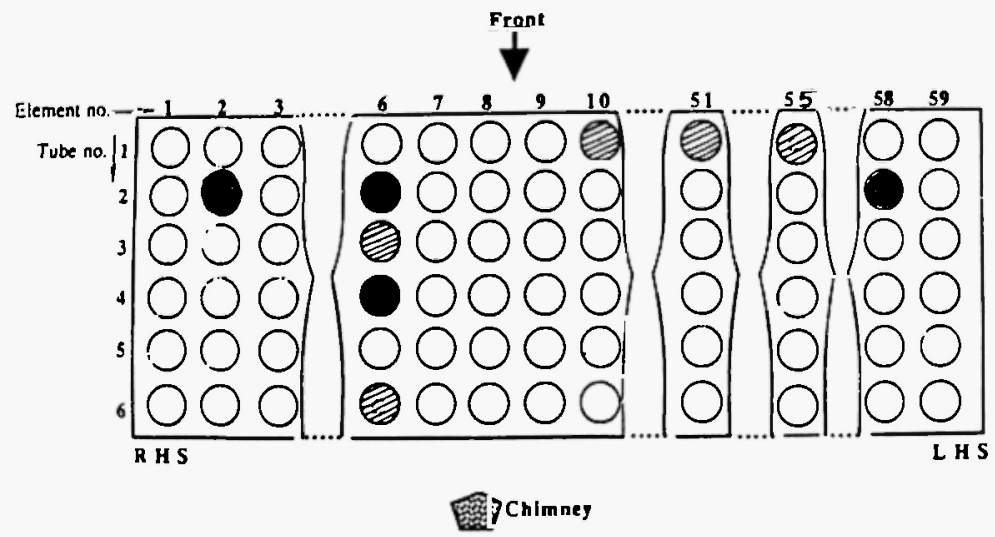

Fig. 3: Schematic layout of pendent superheater tubes of stage 4 in the boiler of a thermal power plant. $O-$ under investigation for Unit No. 1; - under investigation for Unit No. 2. 
Table 2

Hardness values (VPN) of the service-exposed as received pendent superheater tubes

\begin{tabular}{|l|c|c|c|}
\hline Sl. No. & Unit No & Pendent Superheater Tube No. & Hardness (VHN) \\
\hline 1. & 1 & $55 / 1$ & 187 \\
\hline 2. & 1 & $55 / 1$ & 179 \\
\hline 3. & 1 & $6 / 6$ & 150 \\
\hline 4. & 1 & $6 / 6$ & 149 \\
\hline 5. & 2 & $6 / 4$ & 187 \\
\hline 6. & 2 & $6 / 4$ & 167 \\
\hline 7. & 2 & $58 / 2$ & 179 \\
\hline 8. & 2 & $2 / 2$ & 163 \\
\hline 9. & 2 & $22 / 2$ & 163 \\
\hline
\end{tabular}

It may be seen that the hardness lies at $149 \mathrm{VPN}, 20 \mathrm{~kg}$ to $187 \mathrm{VPN}, 20 \mathrm{~kg}$. The hardness is the lowest in the case of tube $6 / 6$ of Unit No. 1 and may be attributed to its higher operating temperature. For Unit No. 2, the hardness of the tubes is compatible, excepting that of the failed tube (6/4) which showed somewhat higher hardness. This could be due to a deformation effect produced either during fabrication and/or some failure.

\subsubsection{Tensile strength}

For studying tensile properties, the two extreme tubes, viz. $6 / 6$ and $55 / 1$, of Unit No. 1 and the failed tube (6/4) of Unit No. 2 were chosen. Tensile tests at room temperature $\left(\mathrm{RT}=25^{\circ} \mathrm{C}\right), 500^{\circ} \mathrm{C}, 550^{\circ} \mathrm{C}$ and $600{ }^{\circ} \mathrm{C}$ of the service-exposed pendent superheater tube material were performed using a software on a digitally controlled 8562 Instron servo-electric testing system, equipped with a 3-zone split furnace with PID control. Standard tensile specimens were made from the service -exposed materials as per ASTM E8-79 specification. Tensile tests were carried out on the base metal only in the longitudinal direction of the service-exposed pendent superheater tubes. During the tensile test, a constant test temperature within $1: 2^{\circ} \mathrm{C}$ and a constant displacement of $0.2 \mathrm{~mm} / \mathrm{min}$ were maintained. The variations of the yield strength $(0.2 \%$ P.S. or Proof Stress) and ultimate tensile strength (UTS) with the test temperature of testing are shown in Figs. 4 and 5 respectively. It is evident from the results that the $0.2 \%$ proof stress (yield strength) and the UTS (ultimate tensile strength) values for the service-exposed tube showed a decreasing trend with increasing temperature. However, \% EL (elongation) showed an increasing trend with increasing test temperature (Fig. 6), which is the general trend observed in service-exposed materials $/ 12 \%$. Tensile test results are displayed in Table 3 . These data have been plotted with reference to NRIM data for the same grade of steel in Figs. 4 and 5 . The NRIM data /12/ represent the minimum property value. It may be seen that the tubes $(6 / 6$ and $55 / 1$ of Unit No. 1 and $6 / 4$ of Unit No. 2 ) have a yield strength above the minimum NRIM/12/ line (Fig. 4). On the other 


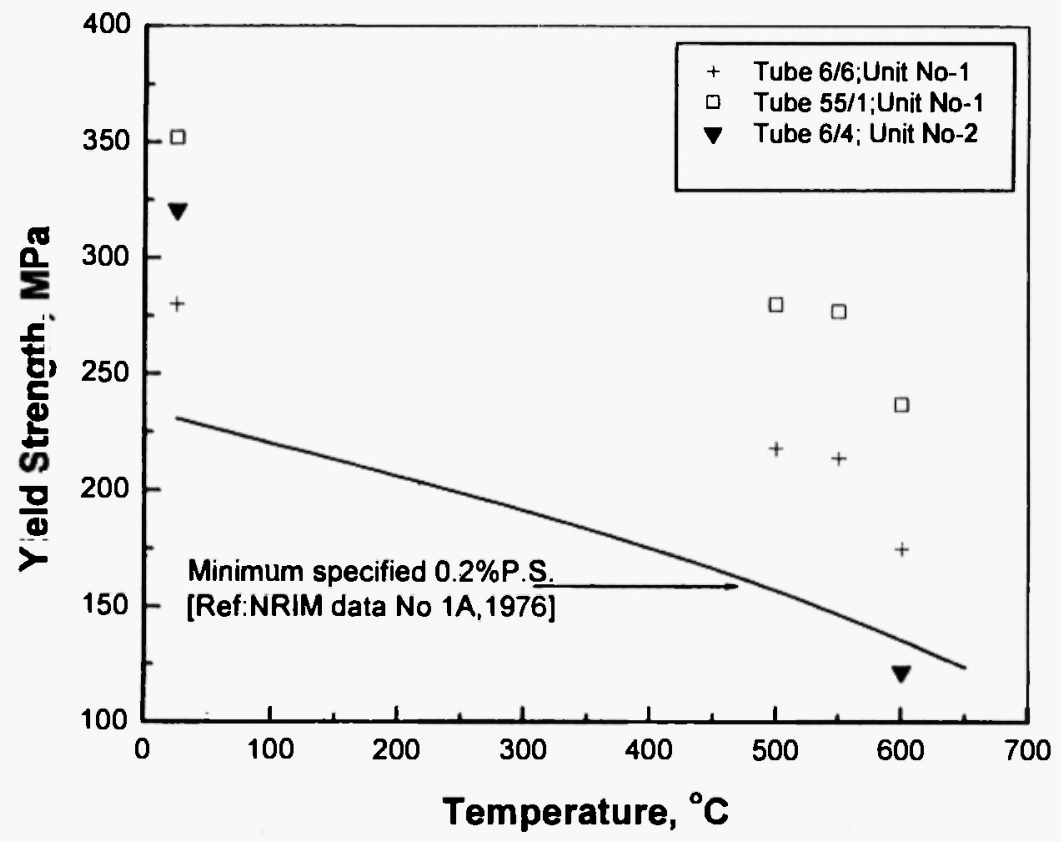

Fig. 4: Test temperature dependence of yield strength (0.2\%P.S) of service-exposed superheater tube

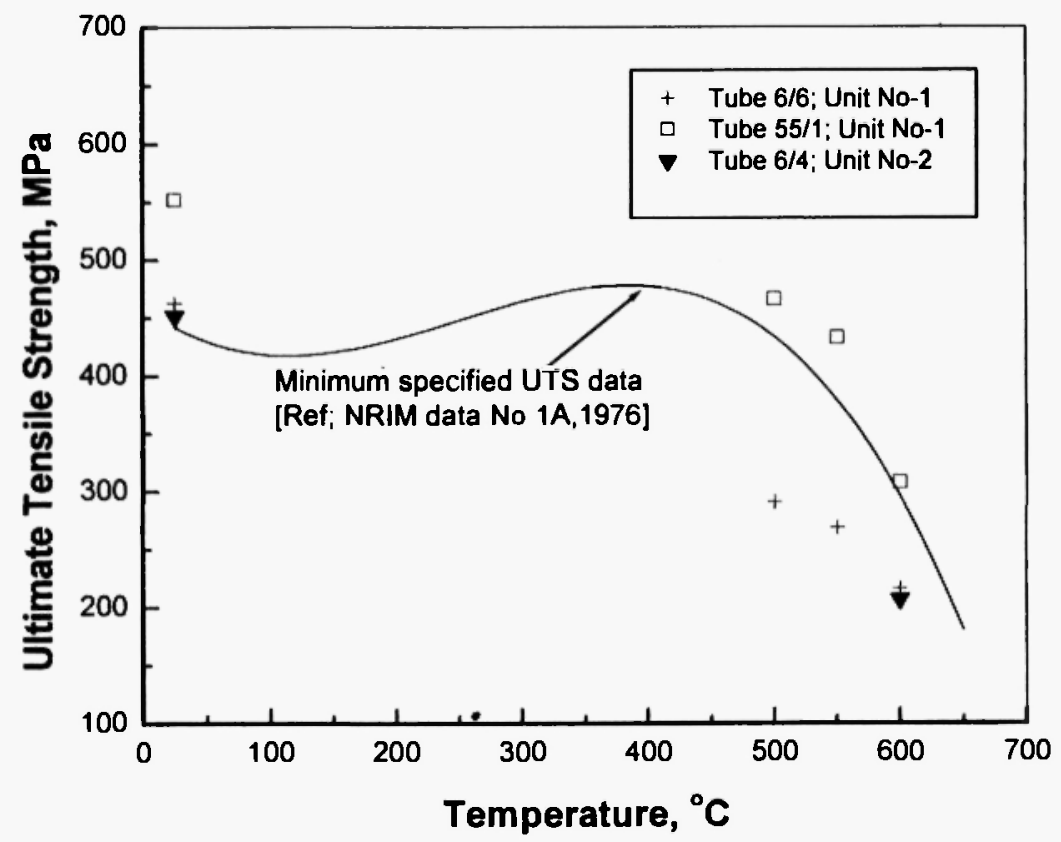

Fig. 5: Test temperature dependence of ultimate tensile strength of service- exposed superheater tubs 


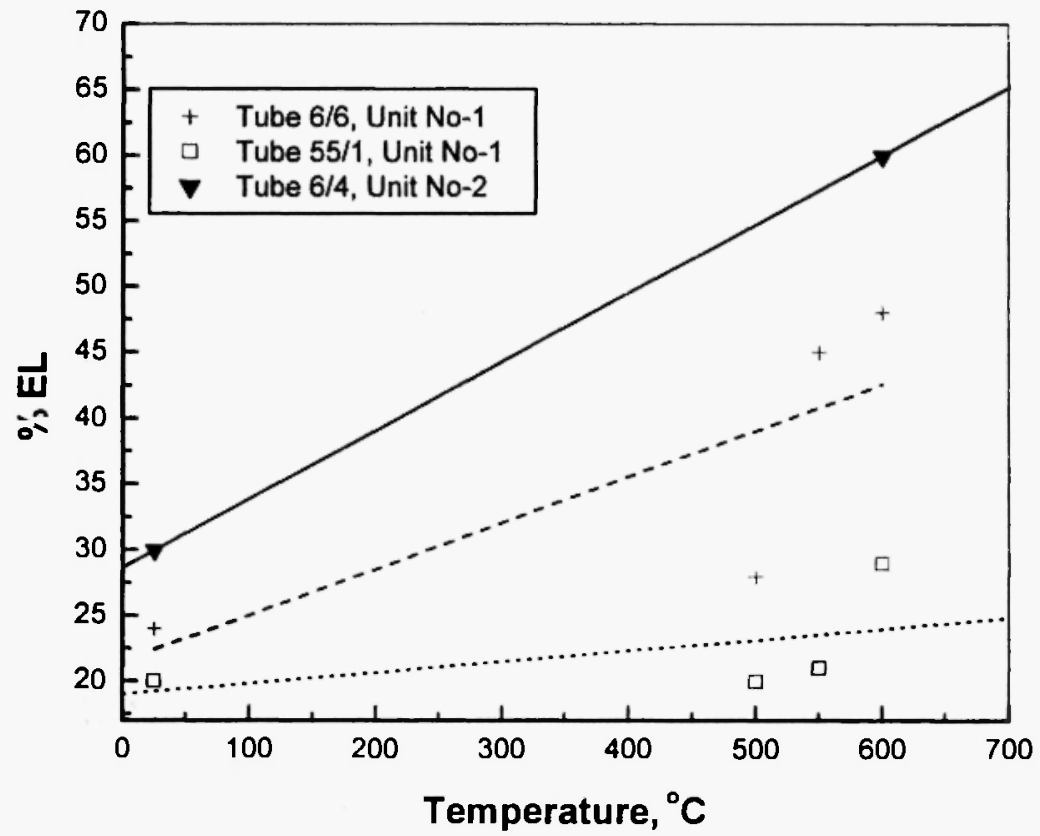

Fig. 6: Variation of \% EL (elongation) with test temperature for service-exposed pendent superheater tubes.

Table 3

Tensile properties of the service-exposed pendent superheater tubes

\begin{tabular}{|l|c|c|c|c|c|c|}
\hline SI No. & Unit No. & Specimens & Temperature $\left({ }^{\circ} \mathrm{C}\right)$ & $\begin{array}{c}\text { Y.S. } \\
(\mathrm{MPa})\end{array}$ & $\begin{array}{c}\text { U.T.S. } \\
(\mathrm{MPa})\end{array}$ & $\%$ EL \\
\hline 1. & 1 & Tube No. 6/6 & $\mathrm{RT}=25$ & 280 & 463 & 24 \\
\hline 2. & 1 & Tube No. 6/6 & 500 & 218 & 291 & 28 \\
\hline 3. & 1 & Tube No. 6/6 & 550 & 214 & 269 & 45 \\
\hline 4. & 1 & Tube No. 6/6 & 600 & 175 & 216 & 48 \\
\hline 5. & 1 & Tube No. 55/1 & $\mathrm{RT}$ & 352 & 552 & 20 \\
\hline 6. & 1 & Tube No. 55/1 & 500 & 280 & 466 & 20 \\
\hline 7. & 1 & Tube No. 55/1 & 550 & 277 & 433 & 21 \\
\hline 8. & 1 & Tube No. 55/1 & 600 & 237 & 308 & 29 \\
\hline 9. & 2 & Tube No. 6/4 & $\mathrm{RT}=25$ & 321 & 452 & 30 \\
\hline 10. & 2 & Tube No. 6/4 & 600 & 122 & 207 & 60 \\
\hline
\end{tabular}

hand, the UTS values at higher temperatures $\left(500-600^{\circ} \mathrm{C}\right)$ of tube $6 / 6$ of Unit No. 1 and tube $6 / 4$ of Unit No. 2 (Fig. 5) were somewhat lower as compared to NRIM data /12/. However, these variations fall within the specified limits for a similar grade of steels, viz. $1 \mathrm{Cr}-0.5 \mathrm{Mo}$ steels, as reported in the literature $/ 12 \%$. 


\subsubsection{Accelerated stress rupture tests}

For accelerated stress rupture tests, tube $6 / 6$ of Unit No. 1 and tube $6 / 2$ of Unit No. 2 were selected, which presumably had experienced a maximum temperature being on RHS of the boiler.

Accelerated stress rupture tests using constant load Mayes creep testing machines were carried out as per ASTM 139/83 specification with flat specimens made from the longitudinal direction of the service-exposed superheater tubes. These tests were carried out in the temperature range of $550-650^{\circ} \mathrm{C}$ and in the stress range of 40-140 MPa. The stress levels above the operating stress at each temperature were selected in such a way as to obtain rupture within a reasonable span of time. The hoop stress $\sigma_{h}$ acting on the service-exposed pendent superheater tubes were calculated using the following formula:

$$
\sigma_{\mathrm{h}}=\mathrm{PD} / 2 \mathrm{t}
$$

where $P$ is the operating pressure in $\mathrm{MPa}, D$ is the mean diameter in mm and $t$ is the thickness of the pendent superheater tube in $\mathrm{mm}$. The operating hoop stress thus evaluated is $\sim 57 \mathrm{MPa}$.

In common practice, in the absence of discernible cavitation, stress rupture tests can be selectively used to assess the condition of components. One of the most widely used techniques for life assessment of components involves removal of samples and conducting accelerated tests at temperatures above the service temperature /8/. An estimate of the remaining life at the operating hoop stress and temperature is then made by analysis creep rupture data using the Larson-Miller Parameter (LMP).

Long-term rupture strengths were estimated with best fitted curves for a first order polynomial, in LMP vs stress plot from each unit. For the first-order polynomial, the average sum square error (ASSE) was estimated from the following equation:

$$
A S S E-\sum\left(Y_{\text {experimental }}-Y_{\text {estimated }}\right)^{\dot{2} / n}
$$

where $n$ is the number of data points. The first-order polynomial was selected for estimation of rupture strength as for higher orders, the polynomial constants $a_{o}$ and $a_{1}$ are zero.

The rupture lives under these test conditions varied between approximately 200-1600 hours. The data have been plotted in terms of stress vs LMP (Larson-Miller Parameter) along with the ASTM (minimum) data line /12/ for a similar grade of steel, for the purpose of comparison (Fig.7). For the grade of steel under the present investigation $/ 12 /$, the Larson- Miller Parameter $(\mathrm{LMP})=\mathrm{T}\left(20+\log \mathrm{t}_{\mathrm{r}}\right)$, where $\mathrm{T}=$ absolute temperature in $\mathrm{K}$ and $\mathrm{t}_{\mathrm{r}}=$ rupture time in hours. Stress rupture data has also been tabulated in Table 4 .

Regression analysis of stress rupture data for service-exposed pendent superheater tubes has been carried out using a standard software package in order to evaluate the long term rupture strength of the tubes over a range of temperatures presently investigated. 


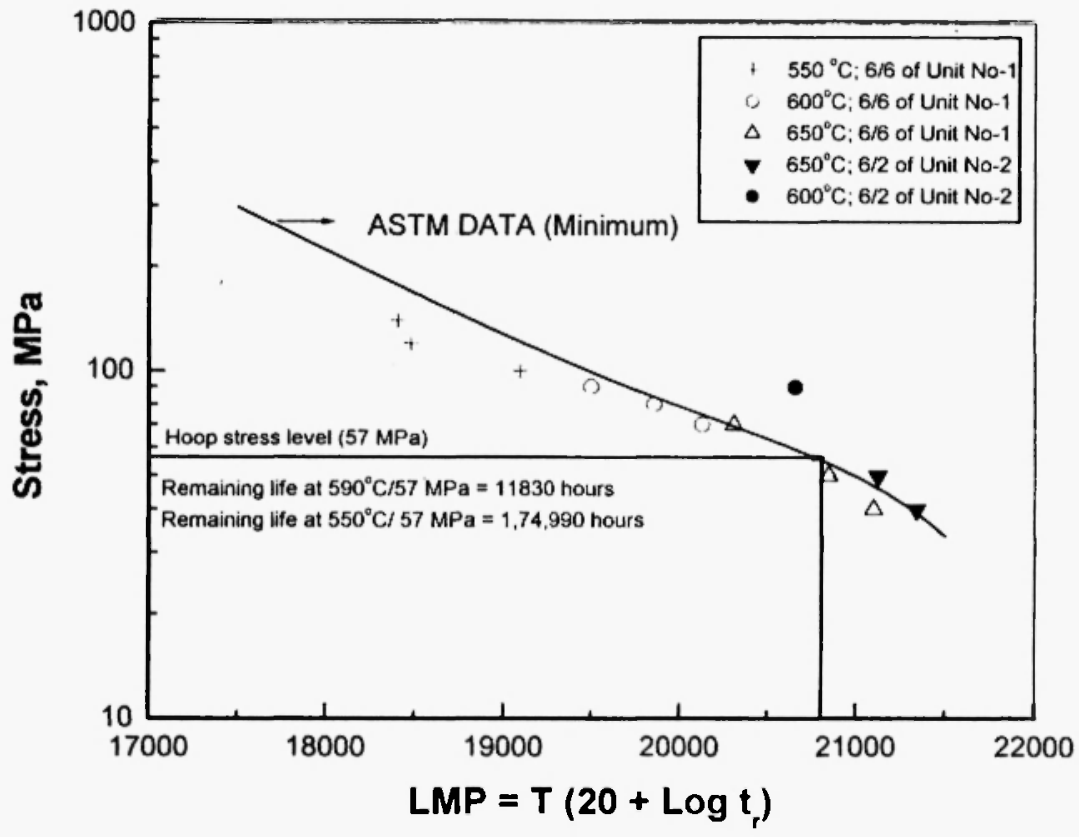

Fig. 7: Stress vs. LMP (Larson Miller Parameter) plot of service - exposed superheater tubes .

Table 4

Stress rupture properties of the service-exposed pendent superheater tubes

\begin{tabular}{|l|c|c|c|c|c|c|}
\hline Sl. No. & Unit No. & Tube No. & $\begin{array}{c}\text { Test Temperature, } \\
\left({ }^{\circ} \mathrm{C}\right)\end{array}$ & $\begin{array}{c}\text { Stress } \\
(\mathrm{MPa})\end{array}$ & $\begin{array}{c}\text { Rupture Time } \\
(\mathrm{hrs})\end{array}$ & $\%$ EL \\
\hline 1. & 1 & $6 / 6$ & 550 & 140 & 231 & 26 \\
\hline 2. & 1 & $6 / 6$ & 550 & 120 & 283 & 32 \\
\hline 3. & 1 & $6 / 6$ & 550 & 100 & 1584 & 28 \\
\hline 4. & 1 & $6 / 6$ & 600 & 90 & 216 & 25 \\
\hline 5. & 1 & $6 / 6$ & 600 & 80 & 554 & 20 \\
\hline 6. & 1 & $6 / 6$ & 600 & 70 & 1128 & 24 \\
\hline 7. & 1 & $6 / 6$ & 650 & 70 & 100 & 30 \\
\hline 8. & 1 & $6 / 6$ & 650 & 50 & 384 & 24 \\
\hline 9. & 1 & $6 / 6$ & 650 & 40 & 720 & 13 \\
\hline 10. & 2 & $6 / 2$ & 650 & 50 & 765 & 21 \\
\hline 11. & 2 & $6 / 2$ & 650 & 40 & 1320 & 20 \\
\hline 12. & 2 & $6 / 2$ & 600 & 90 & 240 & 23 \\
\hline
\end{tabular}


Larson-Miller Parameter $(L M P)=T\left(20+\log t_{r}\right)=a_{0}+a_{l}(\log S)+a_{2}(\log S)^{2}$

$+\ldots \ldots \ldots \ldots .+a_{m}(\log S)^{m}$

where $\quad T=$ temperature in $\mathrm{K}$

$t_{r}=$ rupture time in hrs

$S=$ rupture strength rupture in $\mathrm{MPa}$

$m=$ order of polynomial

$m, a_{m}, a_{1} a_{2}$ and $a_{3}$ are polynomial constants (Table 5)

Table 5

Polynomial constants for regression analysis

\begin{tabular}{|l|c|c|c|c|}
\hline Material & Order of Polynomial & Average sum square error & $\mathrm{a}_{\mathrm{o}}$ & $\mathrm{a}_{1}$ \\
\hline $\begin{array}{l}\text { Pendent Superheater } \\
\text { Tube of Unit. 1 }\end{array}$ & $\mathrm{m}=1$ & $0.173274 \times 10^{\circ}$ & 22444.978 & -29.560227 \\
\hline $\begin{array}{l}\text { Pendent Superheater } \\
\text { Tube of Unit. 2 }\end{array}$ & $\mathrm{m}=1$ & $0.628014 \times 10^{-1}$ & 21824.381 & -13.078571 \\
\hline
\end{tabular}

Table 6 shows the rupture strengths, $\mathrm{S}$, of the service exposed tubes in the temperature range of $550^{\circ} \mathrm{C}$ to $600{ }^{\circ} \mathrm{C}$. The variations of rupture strength with temperature of the service-exposed pendent superheater tubes of Unit No. 1 and Unit No. 2 are revealed in Figs. 8 and Fig. 9 respectively. It is clear from these figures that the estimated 3000-100,000 hr rupture strengths at various temperatures showed a decreasing trend with increasing temperature. This is the general trend observed in service-exposed materials $/ 15 /$.

Since it is not always possible to state the precise residual life in view of some uncertainties including the over-extrapolation, it is also practical to make use of the following criteria to decide about the serviceability of such service-exposed components $/ 11$ /:

a) Time margin $=t_{f} / t_{s}>3$

b) Stress margin $=\sigma_{\text {creep }} / \sigma_{\mathrm{s}}>1.5$

where $\quad t_{s}=$ service life

$t_{f}=$ rupture life at service stress $\left(\sigma_{\mathrm{s}}\right)$

$\sigma_{s}=$ service stress

$\sigma_{\text {creep }}=$ stress for rupture corresponding to the service life

The higher the time margin, the better is the safety of operation for the service-exposed materials. The values of the above margins, as estimated from the creep rupture data in the present investigation for serviceexposed pendent superheater tubes, are summarized in Table 7. 
Table 6

Estimated rupture strength

\begin{tabular}{|c|c|c|c|c|c|c|}
\hline \multirow[t]{2}{*}{ Material } & \multirow[t]{2}{*}{$\begin{array}{c}\text { Order of } \\
\text { polynomial }\end{array}$} & \multirow[t]{2}{*}{$\begin{array}{c}\text { Temperature } \\
\left({ }^{\circ} \mathrm{C}\right)\end{array}$} & \multicolumn{4}{|c|}{$\begin{array}{c}\text { S-rupture strength } \\
(\mathrm{MPa})\end{array}$} \\
\hline & & & $\begin{array}{c}\mathrm{t}_{\mathrm{r}}=3000 \\
\mathrm{hrs}\end{array}$ & $\begin{array}{c}t_{r}=10,000 \\
h r s\end{array}$ & $\begin{array}{c}t_{r}=30,000 \\
h r s\end{array}$ & $\begin{array}{c}\mathrm{t}_{\mathrm{r}}=100,000 \\
\mathrm{hrs}\end{array}$ \\
\hline \multirow{6}{*}{$\begin{array}{l}\text { Pendent } \\
\text { Superheater } \\
\text { Tube of } \\
\text { Unit- } 1\end{array}$} & $m=1$ & 500 & 145.4 & 132 & 119 & 106 \\
\hline & $\mathrm{m}=1$ & 525 & 126 & 111 & 99 & 84 \\
\hline & $m=1$ & 550 & 105.7 & 91 & 77.8 & 63.3 \\
\hline & $\mathrm{m}=1$ & 575 & 86 & 71 & 57 & 42 \\
\hline & $\mathrm{m}=1$ & 590 & 73.9 & 58.6 & 44.7 & 29.4 \\
\hline & $m=1$ & 600 & 70 & 51 & 37 & 21 \\
\hline \multirow{6}{*}{$\begin{array}{l}\text { Pendent } \\
\text { Superheater } \\
\text { Tube of } \\
\text { Unit-2 }\end{array}$} & $\mathrm{m}=1$ & 500 & 281 & 250 & 222 & 191 \\
\hline & $\mathrm{m}=1$ & 525 & 236 & 204 & 175 & 143 \\
\hline & $\mathrm{m}=1$ & 550 & 191.3 & 158.4 & 128.4 & 95.5 \\
\hline & $m=1$ & 575 & 147 & 113 & 82 & 48 \\
\hline & $\mathrm{m}=1$ & 590 & 119.5 & 85 & 53.5 & 19.07 \\
\hline & $m=1$ & 600 & 102 & 67 & 35 & \\
\hline
\end{tabular}

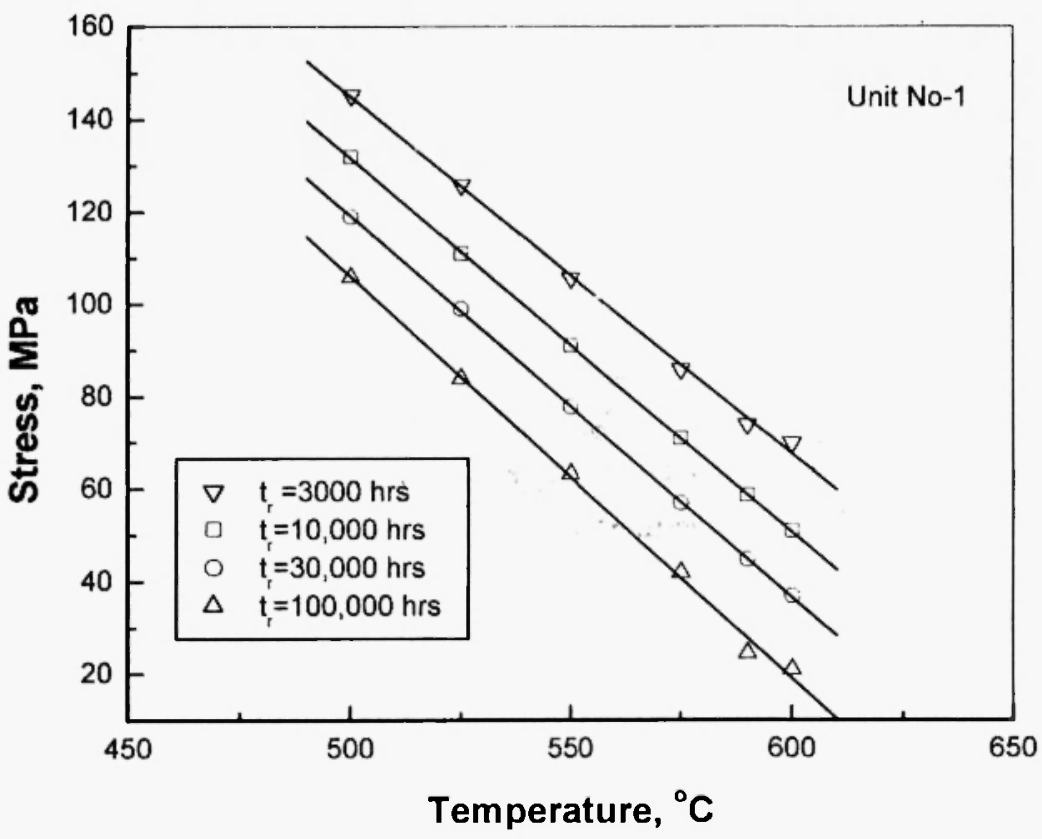

Fig. 8: Plot of rupture strength vs. temperature for service-exposed pendent superheater tubes of Unit No. 1. 


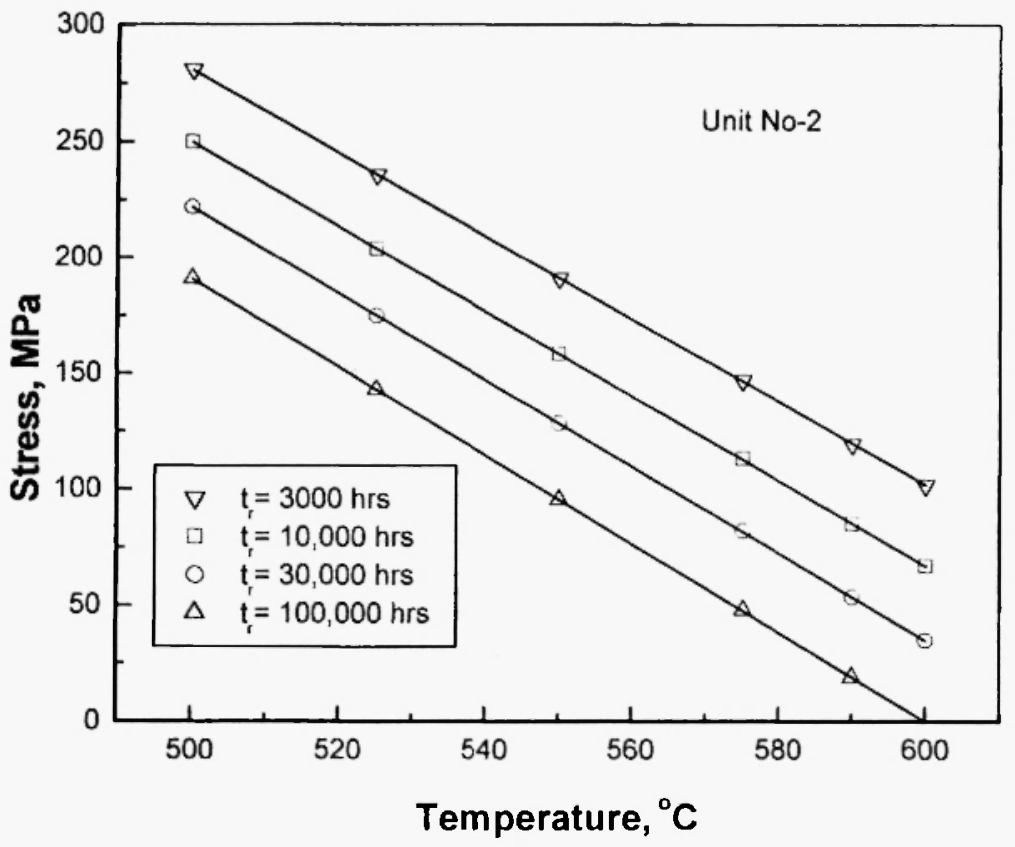

Fig. 9: Plot of rupture strength vs. temperature for service-exposed pendent superheater tube of Unit No. 2.

Table 7

Stress and time margin at $550^{\circ} \mathrm{C}$ at operating hoop stress $57 \mathrm{MPa}$

\begin{tabular}{|l|c|c|c|}
\hline Material & Temperature & Stress Margin & Time Margin \\
\hline $\begin{array}{l}\text { Pendent Superheater Tube } \\
\text { of Unit. 1 }\end{array}$ & $550^{\circ} \mathrm{C}$ & 3.20 & 4.0 \\
\hline $\begin{array}{l}\text { Pendent Superheater Tube } \\
\text { of Unit. 22 }\end{array}$ & $550^{\circ} \mathrm{C}$ & 3.20 & 4.0 \\
\hline
\end{tabular}

It can be seen in Fig. 7 that creep rupture data are closely comparable with the ASTM (minimum) data, excepting a few which were very short term data. However, these data also fall within the $\pm 20 \%$ scatter band of the ASTM data line. It may be said that the steel of the tube has not undergone any degradation in terms of creep rupture strength. The creep ductility of the material in terms of \% EL (elongation) is also satisfactory, as revealed in Table 4.

\subsection{Optical microscopy}

The pendent superheater tubes having minimum and maximum hardness were selected for a microstructural study. Microstructures of the service-exposed tube were examined using an optical microscope. Figs.10(a-b) reveal the microstructures of the tubes $6 / 6$ and 55/1, respectively, of Unit No. 1 . It was observed 


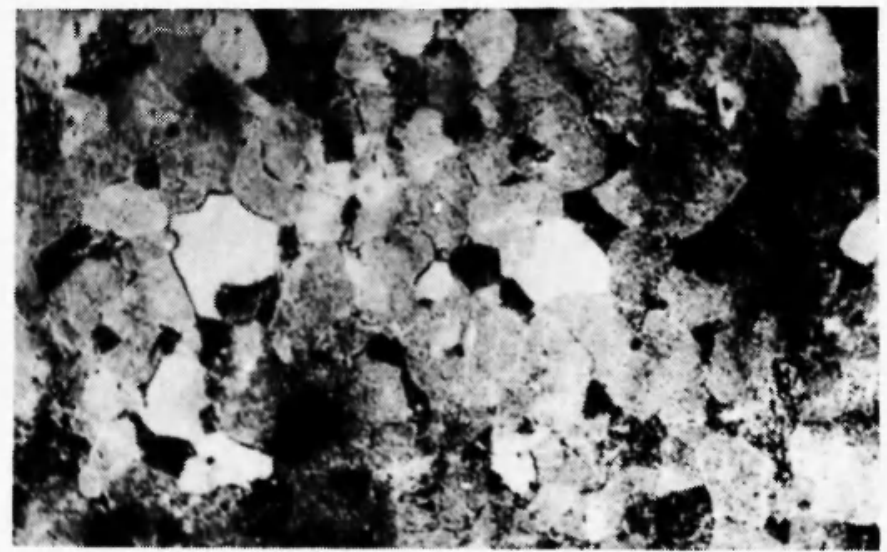

Fig. 10(a): Microstructure of tube $6 / 6$ for Unit No. lat X 300, consisting of ferrite and bainite. There is no evidence of graphitisation or cavitation damage

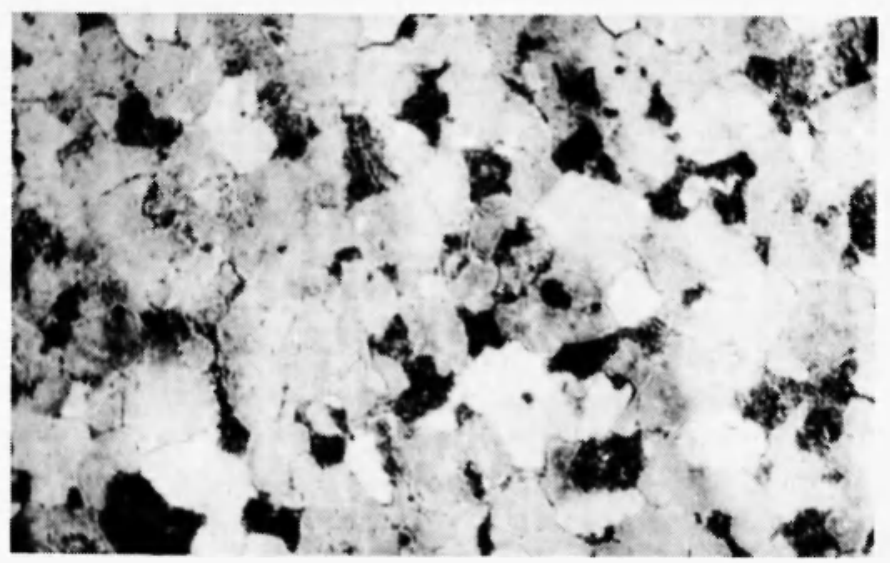

Fig. 10(b) Microstructure of tube 55/1 at X 300 for Unit No. 1, revealing similar structural features as shown in Fig. 3(a). It shows presence of ferrite and bainite. There is no evidence of graphitization or cavitation damage.

that the microstructure consists of ferrite and bainite, which is a typical microstructure of $1 \mathrm{Cr}-0.5 \mathrm{Mo}$ steel. Microstructures did not show any degradation in the form of graphitization, cavitation damage etc. As is evident, there was not much difference between their microstructures. The microstructure of the serviceexposed pendent superheater tube (2/2) of Unit No. 2 revealed a bainitic and ferritic structure (Fig.10c) and partially spheroidized bainitic structure (Fig.10d). No evidence of graphitization and creep damage in the form of cavities was observed (Figs. 10a-d) in any of the service-exposed pendent superheater tubes from Unit No. 1 or Unit No. 2. Therefore, it is clear that the service- exposed pendent superheater tubes have 


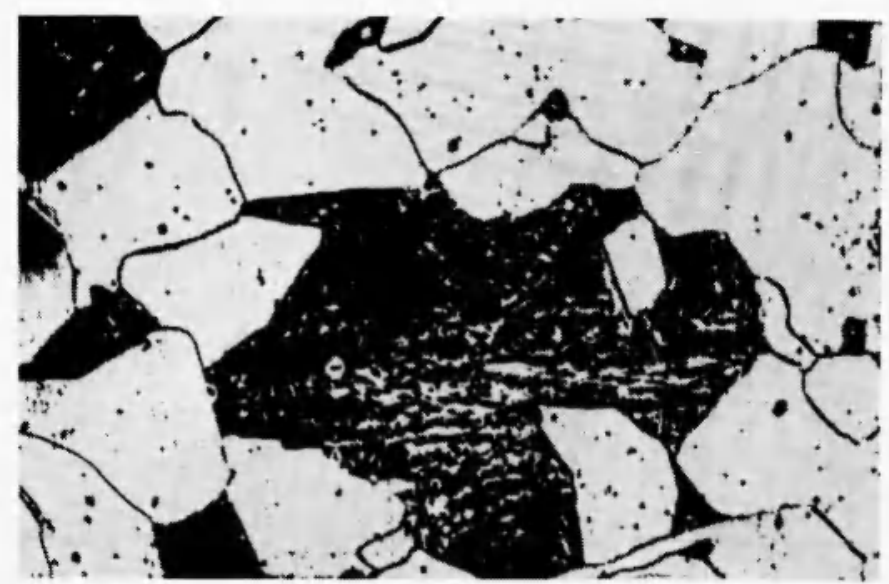

Fig. 10(c): Microstructure of service-exposed pendent superheater tube (2/2) of Unit No. 2 at X 1000 revealing a bainitic and ferritic structure.

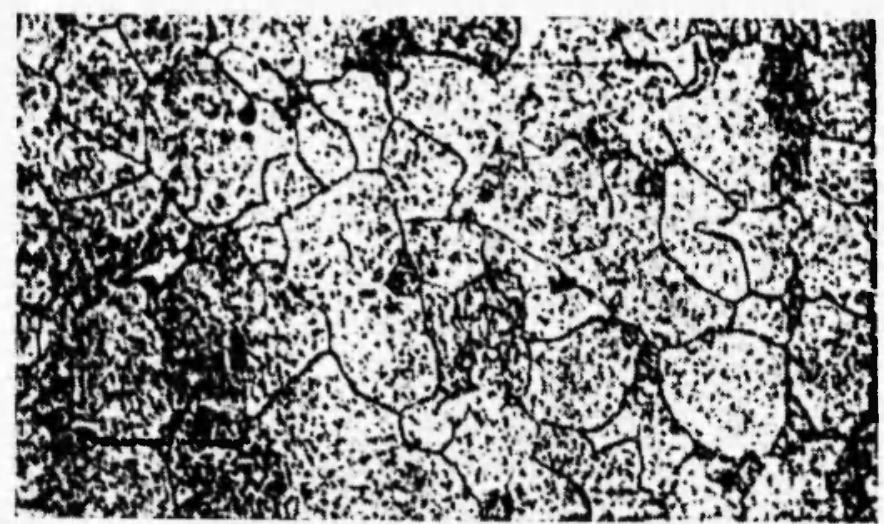

Fig. 10(d) Microstructure of service-exposed pendent superheater tube (2/2) of Unit No. 2 at X100 showing ferritic and partially spheroidized bainitic structure.

hardly undergone any appreciable degradation from the microstructural point of view. Microstructures have not yet shown any damage in the form of a cavity. Oxide scale formed on the inner surface of the tube was also examined and its thickness was measured. In the case of tube $6 / 6$, the oxide scale thickness was nonuniform and had a maximum thickness of $0.12 \mathrm{~mm}$ (Fig.11). In tube 55/1 and also in other tubes, the oxide scale thickness was negligible. 


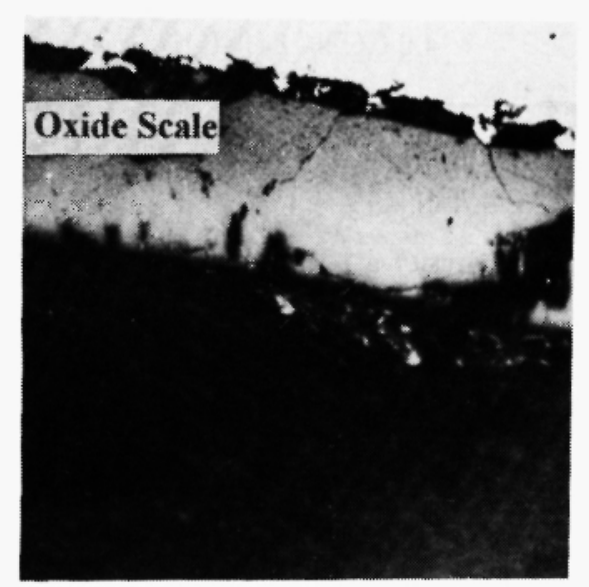

Fig. 11: Optical micrograph at $X 200$ revealing presence of $0.12 \mathrm{~mm}$ thick oxide scale, at the inner surface of tube $6 / 6$ for Unit No. 1 .

\subsection{DISCUSSION}

At the outset it may be mentioned that the major concern in the present investigation pertains to the prevalence of excessive temperature in the boiler stage 4 superheater tubes and its impact on the reliability and remaining service life. Fig. 1 presents the trend of the pendent superheater tube wall temperature over a period of about 1500 hours. These temperatures were measured on the surface of the pendent tube near the roof of the boiler. The maximum temperature recorded was as high as $590^{\circ} \mathrm{C}$ against the design temperature of $480^{\circ} \mathrm{C}$

As far as the remaining life of the pendent superheater tubes at $550^{\circ} \mathrm{C} / 57 \mathrm{MPa}$ is concerned, it would be around 1,74,990 hours (see Fig.7). However, since a peak temperature of $590^{\circ} \mathrm{C}$ was encountered only for a short while, one might consider the minimum life expected at the average temperature which is around $550^{\circ} \mathrm{C}$ (Fig.1). The average operating temperature estimated from oxidation kinetic data is about $535^{\circ} \mathrm{C}$, very close to the average temperature shown in Fig. 1 . At this average temperature $\left(535-550^{\circ} \mathrm{C}\right)$, the minimum expected life would be about 100,000 hours. The reason for upward excursion of temperature in selected tubes could be attributed to non-uniform flow of steam and also to some extent to the physical location of the tubes inside the boiler.

Experimental data like microstructural examination and accelerated stress rupture tests suggest that the majority of the tubes had not undergone any significant degradation that would cause immediate concern. Also, if the tubes operate under normal operating conditions, they would give a minimum life of five years, particularly in those tubes where no dimensional changes in terms of O.D. expansion or wall thinning had taken place. 


\subsection{CONCLUSION}

The pendent superheater tubes, in general, are in a good state of health and can continue to remain in service for a period of about five years provided the specified operating temperature of the tube is properly controlled. It may be desirable to use a superior grade of material like $2.25 \mathrm{Cr}-1$ Mo or a thicker tube of the 1 Cr- 0.5 Mo steel may also be considered, provided the overall load of the panel does not exceed the limit. It is, however, recommended that a similar health check be carried out after five years.

\section{ACKNOWLEDGEMENT}

The authors would like to thank Shri. Santokh Singh, Shri. P.K. Roy and Shri. R.N. Singh for their assistance in the accelerated stress rupture tests. The authors are grateful to Dr. Raghubir Singh, Head, Materials Evaluation Division, National Metallurgical Laboratory, and to Prof. P. Ramachandra Rao, Director, National Metallurgical Laboratory, Jamshedpur, India for their kind permission to publish this paper.

\section{REFERENCES:}

1. D. D'Angelo and A. Percivate, in: Proceedings of International Conference on Creep, Tokyo, Japan, 14-18 April, 1986.

2. I.A. Klevtsov and Kh.A. Tallermo, Teploenergetika, 12, 21 (1996).

3. T. Endo, International J. Pressure Vessel and Piping, 57(1), 7 (1994).

4. M. de Witte, International J. Pressure Vessel and Piping, 39 (1-2), 41 (1996).

5. Y.D. Li, International J. Pressure Vessel and Piping, 69 (2), 161 (1996).

6. I. Klevtsov, H. Tallermo and R.A. Crane, in: Proceedings of International Conference of Plant Condition and Life Measurement, Vol. I, Helsinki, Finland, 6-8 June, 1995), Technical Research Centre of Finland.

7. B. Wilshire, International J. Pressure Vessel and Piping, 39 (1-2), 73 (1989).

8. R. Viswanathan, R. Dooley and A. Saxena, in: Proceedings of International Conference on Life Assessment and Extension, Vol. II, Congress Centre, The Hague, The Netherlands, 13-15 June, 1988; p. 175.

9. A.K. Wingh, A.J. Bagdasarian and V.K. Malhotra, in: NACE. International, Houston, Texas, USA, 1994; p. 21.

10. J. Gabriel Vanderschaeghe and G. Vigneron, in: Proceedings of International Conference on Life Assessment and Extension, Vol. II, Congress Centre, The Hague, The Netherlands, 13-15 June, 1988; p. 136. 
11. T.W. Goodwall and R.A. Ainsworth, CEGB Res., 16, 34 (1984).

12. Data sheets on the elevated temperature properties of $1 \mathrm{Cr}-0.5 \mathrm{Mo}$ steel for boiler and heat exchanger seamless tubes (STBA 22), NRIM creep data sheet, No. 1A, 1976.

13. A.K. Ray, Y.N. Tiwari, R.K. Sinha, S. Chaudhuri and R. Singh, Engineering Failure Analysis, 7 (2), 359 (2000).

14. R. Singh, S. Chaudhuri, A.K. Ray, R.K. Sinha, S.K. Sinha, Y.N. Tiwari, S. Ghosal and C. Guha, Investigation report No. NML IR No. TSP-0013, February, 1997.

15. S. Chaudhuri, "Some aspects of creep behaviour of $2.25 \mathrm{Cr}-1$ Mo steel", Ph.D. Thesis, I.I.T., Kharagpur, 1993. 
